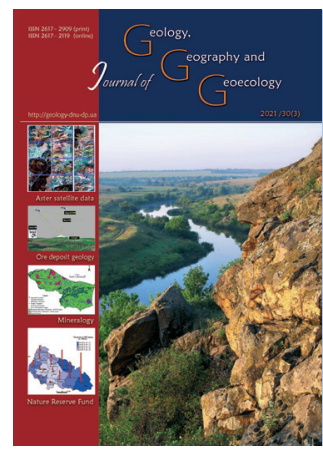

\section{Journal of Geology. Geography and Geoecology}

Journal home page: geology-dnu.dp.ua
ISSN 2617-2909 (print)

ISSN 2617-2119 (online)

Journ. Geol. Geograph. Geology, 30(3), 571-580. doi: $10.15421 / 112152$

Svitlychnyi O. O., Chemerys N. G.

Geol. Geograph. Geoecology, 30(3), 571-580

\title{
Spatially distributed assessment and forecast of soil erosion losses as a basis for optimization the use of erosion-hazardous agricultural lands
}

\author{
Oleksandr O. Svitlychnyi, Nadiia G. Chemerys \\ Odessa I. I. Mechnikov National University, Odesa, Ukraine, e-mail svetlitchnyi.aa.od@gmail.com
}

Received: 26.10 .2020

Received in revised form: 11.04 .2021
Accepted: 14.07.2021

Abstract. The article is devoted to the problem of sustainable use of agricultural lands in conditions of active manifestation of water soil erosion, which is typical for all natural zones of Ukraine, but to the greatest extent - for the Forest-Steppe and Steppe zone. The aim of the article is a spatially distributed quantitative assessment and forecast of soil erosion losses and the development on this basis of recommendations to optimize the use of agricultural land on the example of the Pidhayetskyi district of the Ternopil region. The area is located within the Western region of Ukraine with a fairly high intensity of water erosion, where in accordance with the long-term climate forecast a further increase in erosion hazard of land is expected. A quantitative assessment of soil erosion losses for the basic period (1961-1990) and forecast periods (2031-2050 and 2081-2100) was carried out using a spatially distributed physical-statistical GIS-model of soil erosion-sedimentation developed at the Department of Physical Geography, Nature Management and Geoinformation Technologies of Odesa I. I. Mechnikov National University. Spatial realization of the model performed using the analytical capabilities of the Software for Environmental Modeling PCRaster (University of Utrecht, Netherlands). The forecast of the changes in the hydrometeorological conditions of water soil erosion was made using the forecast of monthly average air temperatures and monthly average precipitation, developed at the Ukrainian Hydrometeorological Institute. It established that most of the arable land (about $52 \%$ ) of Pidhayetskyi district is erosively dangerous. Due to the projected increase in summer rainfall in the middle and at the end of this century, further intensification of soil erosion is expected, especially in 2031-2050, when soil losses on arable land will increase to $16.9 \mathrm{t} / \mathrm{ha} / \mathrm{year}$, and only due to rainstorm erosion. Soil losses by meltwater will be insignificant. Based on the calculations, it was concluded that it is impossible to protect the agricultural lands of the region from erosional degradation without withdrawal from the arable land about 8.15 thousand hectares (28) of the most erosion-hazardous lands (with annual soil losses exceeding 20 tons per a hectare), changing the structure of sown areas and introduction a soil-protective adaptive-landscape farming system over a significant area. Ключові слова: soil erosion, spatially distributed assessment and forecast, optimization of land use, Pidhayetskyi district, Ternopil region.

\section{Просторово-розподілена оцінка і прогноз ерозійних втрат грунту як основа оптимізації використання ерозійно-небезпечних земель}

\author{
О. О. Світличний, Н. Г. Чемерис
}

Одеський національний університет імені I. I. Мечникова, e-mail svetlitchnyi.aa.od@gmail.com 
8.15 тис. га (28 \%) найбільш ерозійно небезпечних земель, зміни структури посівних площ і впровадження на значній площі грунтозахисної адаптивно-ландшафтної системи землеробства.

Ключові слова: водна ерозія, просторово-розподілена оцінка і прогноз, оптимізація землекористування, Підгаєцький район Тернопільської області.

\section{Introduction.}

Comprehensive protection of agricultural land from water soil erosion common in all natural zones of Ukraine can be ensured only on the basis of the use of adaptive-landscape farming systems, such as contour-reclamation, landscape-ecological, precise (Shelyakin et al., 1990; Tarariko, 1990; Kashtanov et al., 1994; Magleby et al., 1995; Bulygin and Nearing 1999; Tarariko, 2005; Vergunov, 2006; Montgomery, 2007; Hobbs et al., 2008; Rykhlivskyi et al., 2014, etc.). The design of adaptive-landscape farming systems requires the use of spatially distributed mathematical models of soil erosion, which make it possible to estimate soil erosion losses on a given slope surface element, taking into account the spatial differentiation of all the main natural and economic factors of slope erosionaccumulative process.

The existing spatially distributed mathematical models of water soil erosion are primarily represented by physically sound dynamic models. The system of differential equations in partial derivatives of the balance of matter (water and sediments) and energy is a basis of these models. However, their high requirements for information support and excessive sensitivity to the accuracy of the input data limit possibility of their usage predominantly by research projects. The practice of conservation farming in different countries is still mainly based on the use of empirical mathematical models of soil erosion, such as the Universal Soil Loss Equation (USLE/RUSLE) (Wischmeier and Smith, 1978; Renard et al., 1997, etc.).

In Ukraine, for design of soil protection from erosion the mathematical models of soil losses developed by Shvebs $(1974,1981)$, Lavrovsky et al. (Lavrovsky et al., 1987), and Sribny (Sribny, 1977; Sribny, Vergunov, 1993), also belonging to the category of empirical mathematical models, are used or are recommended for use. All these models, including the Universal Soil Loss Equation, were originally developed to calculate the average annual soil loss on average for the slope, that is, they were models with lumped parameters that did not take into account the spatial variability of factors of modeled process. At a certain stage, the developers of the Universal Soil Loss Equation proposed a method for approximate accounting for changes in the factors of the erosion process along the length of the slope, but only within its convex part (Foster, Wishmeier, 1974). However, even this model is not properly calibrated and is not tested in the natural and economic conditions of Ukraine.

In recent decades, a spatially distributed physicalstatistical model of soil erosion-sedimentation has developed in the Odessa National I. I. Mechnikov University (Svetlitchnyi, 1995, 1999; Svetlitchnyi et al., 2004; Pyatkova, 2011, 2013; Svetlitchnyi and Piatkova, 2019). Currently, this mathematical model is software implemented using the operators of the Software for Environmental Modeling (GIS-package) PCRaster (PCRaster ..., 2018) and the programming language Basic. The model was successfully verified using observational data at runoff plots and experimental catchments of the Moldavian and VelikoAnadol Water Balance Stations and the Boguslav Field Research Hydrological Base of the Ukrainian Hydrometeorological Institute (UkrHMI) (Svetlitchnyi, 1995, Piatkova, 2011; Svetlitchnyi and Piatkova, 2019), as well as of the results of field studies of water erosion using the radio-cesium method and the method of magnetic tracers (Zhidkin et al., 2015). The adequacy of modeling the spatial distribution of erosionsedimentation by this model was also confirmed by comparison with the simulation results using the spatially distributed physically based dynamic model LISEM (Svetlitchnyi, Pyatkova, 2017). Recent studies on longterm forecasting of climate change (Krakovska et al., 206; Krasovska et al., 2017), surface runoff (Gopchenko et al., 2012; Ovcharuk. 2017) and hydrometeorological conditions of soil erosion (Svetlitchnyi, 2018) make it possible to use this model not only for a spatially distributed assessment, but also for a forecast of soil erosion within the plain part of Ukraine until 2100.

The purpose of this study is the spatially distributed quantitative assessment and forecast of erosion losses of soil and the development on this basis of recommendations to optimize the use of agricultural land on the example of the Pidhayetskyi district of the Ternopil region. The area is located within the Western region of Ukraine with a fairly high intensity of soil erosion where, in accordance with the long-term climate forecast, a further increase in erosion hazard is expected, at least during the warm season (Svetlitchnyi, 2018).

Water erosion losses of soils on the agricultural lands of the Pidhayetskyi region is the object of the study. Spatially distributed retrospective assessment of erosion losses of soil for the baseline period (19611990), their forecast until 2100 and the development of recommendations for optimization the use of erosionhazardous lands of the region is a subject of the study.

\section{Material and methods of research.}

Pidhayetskyi district is located in the western part of the Ternopil region on the border of the Western Podillya and the Eastern Opilia on the Volyn-Podilsk 
Upland. The territory of the district is 49638 ha (496.38 $\mathrm{km}^{2}$ ) (Pidgajec'ka..., 2018).

The relief of the territory is wavy, crossed by river valleys of mainly meridian strike and beams, in the western part of it is hilly. The absolute heights of the divides are $380-410 \mathrm{~m}$, and of the bottoms of river valleys (the Zolotaya Lipa, Koropets, Strypa rivers) are 240-330 m. The maximal height of the earth's surface within the district is $414 \mathrm{~m}$. The distribution of the Pidhayetskyi district agricultural land in the range of slope gradients is shown in the Table 1.

Table 1. Distribution of the Pidhayetskyi district agricultural land in the range of slope gradients

\begin{tabular}{|c|c|c|}
\hline \multirow{2}{*}{$\begin{array}{c}\text { Slope gradients, } \\
\text { degrees }\end{array}$} & ha & $\%$ \\
\cline { 2 - 3 } & 7356.5 & 20.7 \\
\hline$<1$ & 11724.5 & 33.0 \\
\hline $1-3$ & 7741.3 & 21.8 \\
\hline $3-5$ & 4157.0 & 11.7 \\
\hline $5-7$ & 4538.5 & 12.8 \\
\hline$>7$ & 35517.8 & 100.0 \\
\hline Total & & \\
\hline
\end{tabular}

The climate of the district is temperate continental and is characterized by mild winters, warm summers, and a significant amount of rainfall. The area is located at the boundary of two climatic zones: of the Western European zone in the west with a humid and moderately warm climate and East-Continental zone in the East with a continental climate (Geografija ..., 2017). The average annual air temperature according to Berezhany meteorological station, which is located $25 \mathrm{~km}$ northwest from the administrative center of the district, is $7.2^{\circ} \mathrm{C}$, the average annual rainfall amount according to Berezhany meteorological station is $690 \mathrm{~mm}$, according to the precipitation measuring post Pidhaitsi - $704 \mathrm{~mm}$. (Klimatychnyj..., 2006). Most precipitation falls in the warm part of the year (April-October). The maximal rainfall in a single rain at Berezhany weather station was observed in August and reached $90 \mathrm{~mm}$. The period 1961-1990 was characterized by a persistent winter with average monthly temperatures of $-2.1 \ldots-4.9{ }^{\circ} \mathrm{C}$, with an average duration of snow cover of 84 days and an average maximal height of $37 \mathrm{~cm}$ in the end of winter (Klimatychnyj..., 2006).

The soil cover in the eastern part of the district (in the Podillya) is represented by podzolized chernozems and dark gray podzolized coarse-dusty medium loamy soils and in the western part (at Opilia) by gray and light gray podzolized loamy soils.
Podzolized chernozems in comparison with dark gray podzolized soils are deeper, more humus-rich (2.5$3.5 \%$ ). Gray and light gray podzolized soils of Opilia in the upper horizons have a humus content of $1.8-2.2 \%$. The natural fertility of these soils is much less than that of the chernozems (Geography..., 2017).

Among 49638.00 hectares of land under the control of Pidhayetskyi district, agricultural land occupies 35517.79 or $71.6 \%$ of the total area, including arable land -29047.53 hectares $(81.8 \%)$, pastures -4702.49 ha $(13.2 \%)$, hayfields -1376.47 ha $(3.9 \%)$, perennial plantings -391.29 ha (1.1\%). In addition, 451.49 hectares $(1.3 \%)$ are under farm buildings and yards, forests cover 9365 hectares (18.9\% of the area), reservoirs -592 hectares $(1.2 \%)$, swamps -212 hectares $(0.4 \%)$ (Pidgajec'ka..., 2019).

The structure of sown areas of the district is presented in the Table. 2. The largest share in the structure of sown areas is occupied by cereal crops, which account for $50.8 \%$ of the arable land, including $23.6 \%$ of spring crops and $27.2 \%$ of winter crops. The group of high-stem tilled crops (corn, sorghum, sunflower), whose soil-protective efficiency is very low, occupies $29.7 \%$ of the arable land area. Perennial grasses with high soil-protective efficiency occupy only $3.5 \%$ of the sown area.

Table 2. Structure of sown areas of the Pidhayetskyi district (Pidgajec'ka..., 2019)

\begin{tabular}{|c|l|c|c|}
\hline No & \multicolumn{1}{|c|}{ Crops } & Area, ha & $\begin{array}{c}\text { Share in the structure of sown } \\
\text { areas, } \%\end{array}$ \\
\hline 1 & High-stem tilled crops (corn, sorghum, sunflower) & 8640.6 & 29.7 \\
\hline 2 & $\begin{array}{l}\text { Low-stem tilled crops (soybeans, buckwheat, peas, potatoes, } \\
\text { vegetables, watermelons and melons) }\end{array}$ & 4264.1 & 14.7 \\
\hline 3 & Spring cereals & 6841.0 & 23.6 \\
\hline 4 & Winter cereals & 7887.1 & 27.2 \\
\hline 5 & Annual grasses & 388.1 & 3.3 \\
\hline 6 & Perennial grasses & 1026.6 & 100.0 \\
\hline & & 29047.5 & \\
\hline
\end{tabular}


A quantitative assessment of soil erosion losses on agricultural lands of the Pidhayetskyi district of the Ternopil region was performed using a spatially distributed version of the physical-statistical model of soil erosion-sedimentation (Svetlitchnyi, 1995, 1999; Piatkova, 2008,2011; Svetlitchny \& Piatkova, 2019). The years 1961-1990 were chosen as the baseline period due to the availability for this period of a complete set of information necessary for the model. The forecast was made for the middle of the current century (2031-2050) and its end (2081-2100) in accordance with the periods of the long-term climate forecast developed at UkrHMI (Krasovska et al., 2016; Krasovska et al., 2017).

The digital geodatabase for the territory of Pidhayetskyi district has been created using a topographic map of 1:100000 scale, a soil map of 1:200000 scale (Karta gruntiv..., 1967) and high-resolution satellite image from the GoogleEarth Internet service. Statistical materials from the website of the Pidhayetska State Administration, monographic literature and publications in the periodical scientific editions were used as a source of attributive information characterizing the use of land in the region. The values of climatic indicators for the baseline period were taken from the Climatic Cadaster of Ukraine (Klimatychnyj..., 2000), for forecast periods - taken in accordance with the climate forecast made in the Ukrainian Hydrometeorological Institute (Krakovska et al., 2016; Krakowska et al., 2017).

Comparative-geographical, cartographic, statistical and geoinformation modeling methods were used to achieve the purpose. The PCRaster environmental modeling package developed in the Department of Physical Geography of the University of Utrecht, the Netherlands (PCRaster ..., 2018) was used as the basic GIS software.

\section{Results and Discussion.}

Creating the digital geodatabase. The digital database of spatially distributed data (geodatabase) includes sets of basic and derived digital maps of the district area. Digital raster maps created on the basis of digitizing of paper maps or a satellite image we will consider as basic maps. Digital raster maps created on the basis of basic digital maps using GIS software tools we will consider as derived maps.

The hydrologically correct digital elevation model, digital maps of soils and land use are the basic digital data layers that provide a mid-scale assessment of erosion soil losses within an administrative district based on the physical-statistical model of ONU. Screen copies of these three basic digital maps for the territory of the Pidhayetskyi district of the Ternopil region are presented in the Figures 1-3.

All basic maps are built in the WGS-84 UTM coordinate system with the same spatial resolution. The raster cell size is $50 \mathrm{~m}$ for all maps. When constructing a digital elevation model on a topographic map of 1 : 100000 scale all the main and additional relief contour lines were digitized, as well as the structural elevation lines (divides and talwegs). Spatial interpolation of point data was performed using methods of ordinary point kriging and radial basis functions, which gave similar results.

The set of derived maps includes a large number of digital raster maps, most of which are created in batch mode using capabilities of the Basic and PCRaster packages. Digital raster maps of slope gradients, expositions, streamlines, relative erodibility and partial characteristic of relative erodibility of soils, horizontal gradients of soil cover characteristics, in particular, are derivative maps are creating the process of implementation of the erosion-sedimentation model.

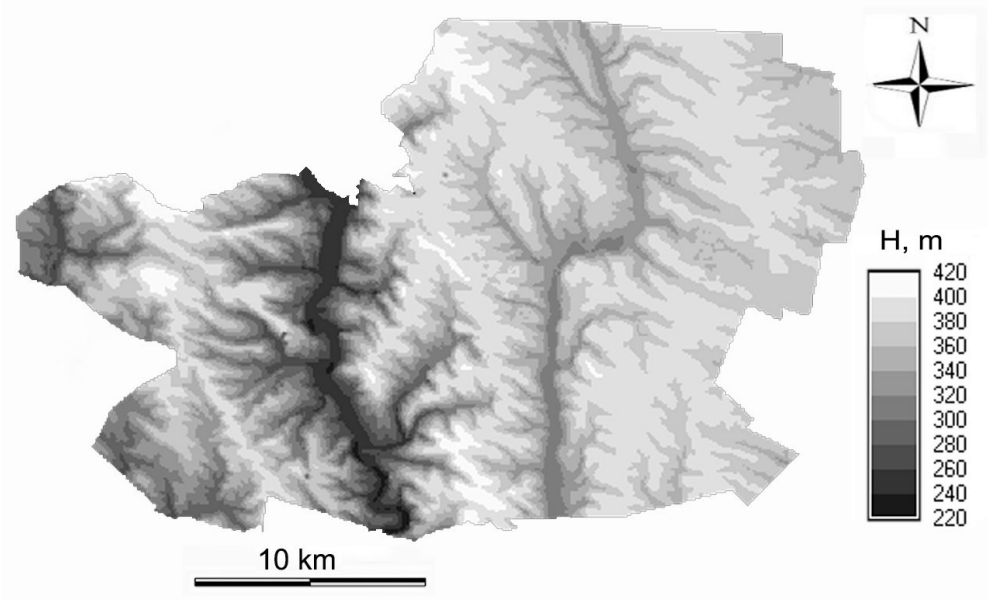

Fig. 1. Screen copy of digital elevation map of the Pidhayetskyi district 


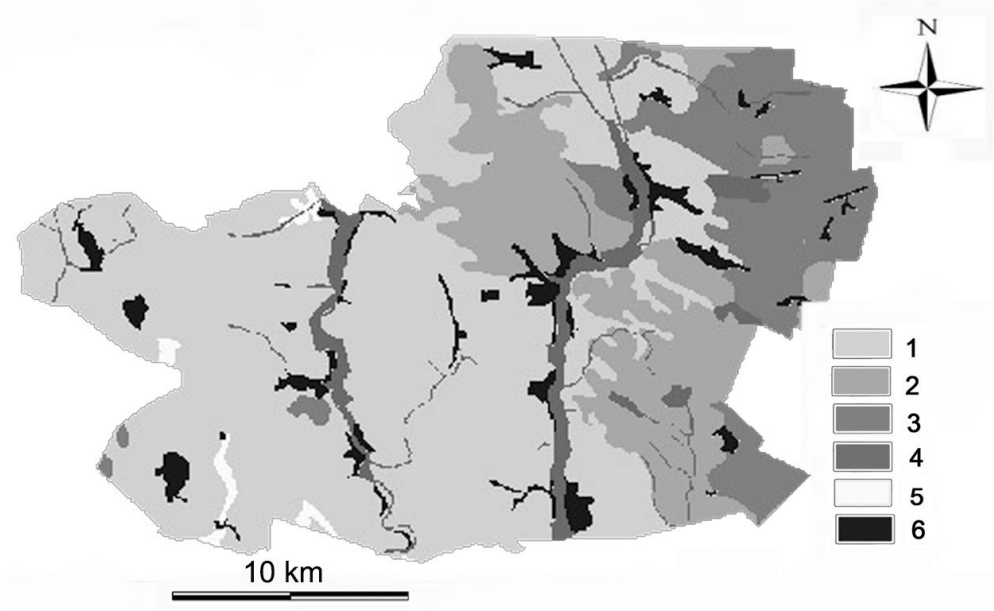

Fig. 2. Screen copy of soil map of the Pidgayetskyi district: 1 - light-gray and gray podzolized soils; 2 - dark-gray podzolized soils; 3 - podzolized chernozems; 4 - meadow-chernozem, chernozem-meadow, meadow, meadow-bog and other alluvial soils; 5 - exits of rocks; 6 - settlements

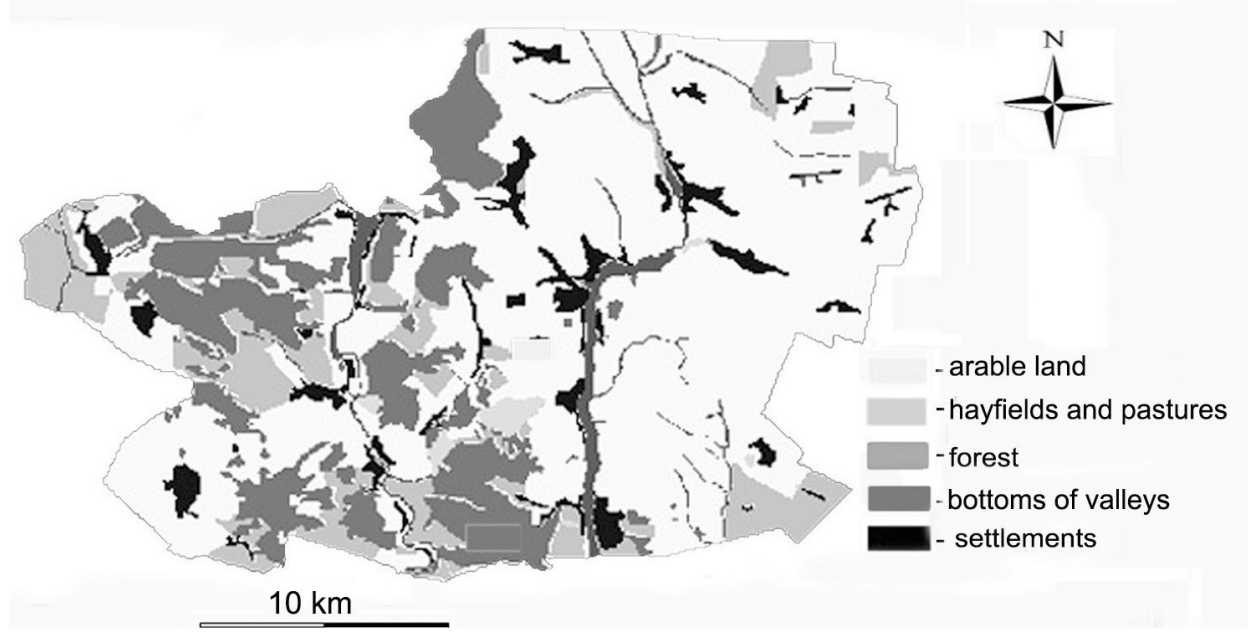

Fig. 3. Screen copy of land use map of the Pidhayetskyi district

Parameterization of the model. The hydrometeorological factor of rainstorm soil losses $\left(K_{H M}\right)$ and the hydrometeorological factor of soil losses by the meltwater $\left(K_{H M S}\right)$ are the main parameters of the used model of soil erosion, requiring geographical reference. The long-term average the $K_{H M}$ values for the baseline climate period and for the forecast periods are determined by the previously established dependence of the $K_{H M}$ on the long-term average sum of precipitation for May-September (Svetlitchnyi, 2018). The longterm average value of the hydrometeorological factor of rainstorm losses of soil for the baseline period, obtained using this dependence and the data from the precipitation measuring station Pidhaitsi (Klimatychnyj..., 2006), is 0.0052 . The long-term average values of the $K_{H M}$ for 2031-2050 and 2081-2100 in accordance with the forecast of monthly precipitation (Krakowska et al., 2017) (Table 3) are 0.0071 and 0.0063 , respectively. Due to the fact that the forecast of changes in the average monthly precipitation for 2031-2050 and 2081-2100 is given in relation to 1991-2010, it became necessary to assess the change in the average monthly precipitation of 1991-2010 in relation to the baseline period (1961-1990). This assessment was performed using observational data from the reference weather stations of the region. 
Table 3. Long-term average precipitation for May-September for the Pidhaitsi precipitation measuring post for the baseline period in accordance with the Climatic Cadaster of Ukraine (Klimatychnyj..., 2000) and for forecast periods for Western Region of Ukraine in accordance with (Krakowska et al., 2017)

\begin{tabular}{|c|c|c|c|c|c|c|}
\hline & May & June & July & August & September & Sum \\
\hline Average long-term precipitation for $1961-1990, \mathrm{~mm}$ & 71 & 98 & 98 & 72 & 62 & 406 \\
\hline $\begin{array}{l}\text { Change in precipitation } 1991-2010 \text { in relation to } 1961- \\
1990, \%\end{array}$ & -7 & -12 & 4 & 10 & 35 & \\
\hline Average long-term precipitation for $1991-2010$ years, $\mathrm{mm}$ & 66 & 86 & 102 & 79 & 84 & 420 \\
\hline \multicolumn{7}{|c|}{$2031-2050$} \\
\hline $\begin{array}{l}\text { Projected precipitation changes relative to } 1991-2010 \\
\text { years, } \%\end{array}$ & 16 & 12 & 13 & 4 & 18 & \\
\hline Average long-term precipitation for $2031-2050$ years, $\mathrm{mm}$ & 77 & 96 & 115 & 82 & 99 & 469411 \\
\hline \multicolumn{7}{|l|}{ 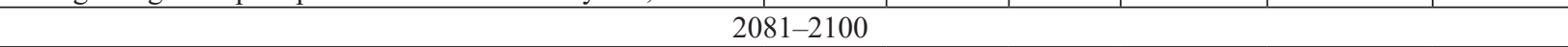 } \\
\hline $\begin{array}{l}\text { Projected precipitation changes relative to } 1991-2010 \\
\text { years, } \%\end{array}$ & 7 & 4 & 13 & -3 & 10 & \\
\hline Average long-term precipitation for $2081-2100, \mathrm{~mm}$ & 71 & 89 & 115 & 77 & 92 & 444 \\
\hline
\end{tabular}

The long-term average value of the hydrometeorological factor of spring snowmelt erosion $\left(K_{H M S}\right)$ for the baseline period in accordance with (Svetlitchnyi et al., 2004) equals to 0.0010 . The $K_{H M S}$ values for the forecast periods (2031-2050 and 2081$2100)$ in accordance with the forecast of spring surface runoff values (Gopchenko et al., 2012; Ovcharuk, 2017) are either close to zero (in the middle of the century) or equal to zero (in end of the century). That is, the erosion hazard of the district's agricultural lands in the prospect under consideration will be determined only by rainstorm erosion during a warm season.

The values of other parameters of the model are taken in accordance with the existing recommendations (Shvebs, 1981; Svetlitchnyi et al., 2004; Lisetsky et al., 2012).

Results of calculation and forecast of soil erosion losses. The result of the calculation of soil erosion losses within the Podhayetskyi district for hydrometeorological and land use conditions of the baseline period (19611990) are presented in the Fig. 4. The result of the calculation of soil erosion losses within the most erosion-prone arable land are presented in the Table 4.

The analysis in the Fig. 4 and the Table 4 allows us to state a generally high rate of erosion degradation of soils of arable lands of the district. Within hayfields and pastures, which make up the second main component of the farmland of the district, soil erosion losses are usually insignificant. This circumstance allows us to focus on the analysis of soil erosion losses precisely on arable land, occupying $81.8 \%$ of the farmland and $58.5 \%$ of the total district's area. The calculated average module of erosion losses of soils within the arable land of the district for the baseline period is $16.0 \mathrm{t}$ /ha per year (Table 4). Most of the soil erosion losses, namely $13.6 \mathrm{t} /$ ha/year or $85 \%$, are formed by rainfall in warm season, $2.5 \mathrm{t} / \mathrm{ha} /$ year $(15 \%)$ - by melt water in spring. The area of arable land with annual soil losses not exceeding $5 \mathrm{t} /$ ha/year is 14056 ha or $48.4 \%$. The area of arable land with erosion losses exceeding $20 \mathrm{t} / \mathrm{ha} /$ year is about 6720 ha or $23.1 \%$ of its area. Within 2407 ha $(8.3 \%)$ of arable land, the estimated soil loss exceeds $50 \mathrm{t} / \mathrm{ha} /$ year.

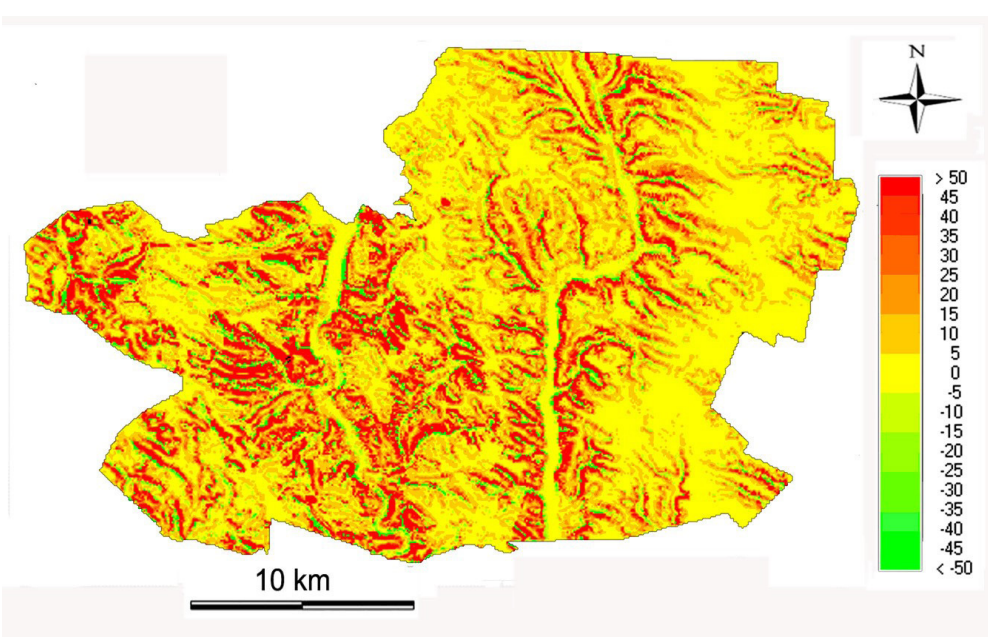

Fig. 4. The estimated average annual soil losses ( $\mathrm{t} / \mathrm{ha} / \mathrm{year})$ within the Pidhayetskyi district for the baseline period 
Table 4. Average annual soil losses ( $\mathrm{t} / \mathrm{ha} / \mathrm{year}$ ) and distribution of the area of arable land of the district by gradations of erosion losses for the baseline period

\begin{tabular}{|c|c|c|c|c|c|c|c|c|c|c|c|c|c|c|}
\hline \multirow[b]{2}{*}{$\begin{array}{l}\text { Period, } \\
\text { years }\end{array}$} & \multirow[b]{2}{*}{$\begin{array}{c}\text { Season, } \\
\text { year }\end{array}$} & \multicolumn{2}{|c|}{$<2$} & \multicolumn{2}{|c|}{$2-5$} & \multicolumn{2}{|c|}{$5-10$} & \multicolumn{2}{|c|}{$10-20$} & \multicolumn{2}{|c|}{$20-50$} & \multicolumn{2}{|c|}{$>50$} & \multirow[b]{2}{*}{$\begin{array}{c}\text { Average annual } \\
\text { soil losses, } t / \\
\text { ha/year }\end{array}$} \\
\hline & & $\begin{array}{c}\text { Area, } \\
\text { ha }\end{array}$ & $\%$ & $\begin{array}{c}\text { Area, } \\
\text { ha }\end{array}$ & $\%$ & $\begin{array}{c}\text { Area, } \\
\text { ha }\end{array}$ & $\%$ & $\begin{array}{c}\text { Area, } \\
\text { ha }\end{array}$ & $\%$ & $\begin{array}{c}\text { Area, } \\
\text { ha }\end{array}$ & $\%$ & $\begin{array}{c}\text { Area, } \\
\text { ha }\end{array}$ & $\%$ & \\
\hline \multirow{3}{*}{$\begin{array}{c}1961- \\
1990\end{array}$} & $\begin{array}{c}\text { Summer } \\
\text { autumn }\end{array}$ & 9960 & 34.3 & 4412 & 15.2 & 3935 & 13.6 & 4088 & 14.1 & 4246 & 14.6 & 2407 & 8.3 & 13.6 \\
\hline & Spring & 17012 & 58.6 & 7555 & 23.0 & 3317 & 11.4 & 1019 & 3.5 & 145 & 0.5 & 0 & 0 & 2.5 \\
\hline & Year & 8546 & 29.4 & 5510 & 19.0 & 3917 & 13.5 & 4356 & 15.0 & 4314 & 14.8 & 2407 & 8.3 & 16.0 \\
\hline
\end{tabular}

In the middle of current century (2031-2050), in accordance with the predicted climate change (Table 3 ) while maintaining the structure of sown areas, the soil cultivation system, and the absence of special antierosion measures the erosion hazard of arable land in the district will increase, despite a decrease to insignificant values of erosion losses of soil in spring. The area of arable land with an average annual soil losses exceeding on tho wrill amount to 8152 ho $/ 7810 /$ ) that is it wrill increase by 1434 ha or $4.9 \%$ compared to the baseline period. Accordingly, an area of land with erosion soil losses of less than $5 \mathrm{t} / \mathrm{ha} /$ year will decrease by 954 ha (up to 13102 ha or up to $45.1 \%$ ). At the end of the century (2081-2100), due to the projected decrease compared to 2031-2050 the amount of precipitation in the warm season, soil erosion losses on the arable lands of the district will slightly decrease (Table 5).

Table 5. Forecast of the average annual soil losses and distribution of the arable land area of the Pidhayetskyi district according to gradations of erosion soil losses ( $\mathrm{t} / \mathrm{ha} /$ year)

\begin{tabular}{|c|c|c|c|c|c|c|c|c|c|c|c|c|c|c|}
\hline \multirow{2}{*}{$\begin{array}{c}\text { Period, } \\
\text { years }\end{array}$} & $\begin{array}{c}\text { Season, } \\
\text { year }\end{array}$ & $\begin{array}{c}\text { Area, } \\
\text { ha }\end{array}$ & $\%$ & $\begin{array}{c}\text { Area, } \\
\text { ha }\end{array}$ & $\%$ & $\begin{array}{c}\text { Area, } \\
\text { ha }\end{array}$ & $\%$ & $\begin{array}{c}\text { Area, } \\
\text { ha }\end{array}$ & $\%$ & $\begin{array}{c}\text { Area, } \\
\text { ha }\end{array}$ & $\begin{array}{c}\text { \% } \\
\%\end{array}$ & $\begin{array}{c}\text { Area, } \\
\text { ha }\end{array}$ & $\begin{array}{c}\text { Average } \\
\%\end{array}$ & $\begin{array}{c}\text { annual soil } \\
\text { losses, } \mathrm{t} / \\
\text { ha/year }\end{array}$ \\
\hline $2031-2050$ & $\begin{array}{c}\text { Summer- } \\
\text { autumn }\end{array}$ & 8423 & 29.0 & 4679 & 16.1 & 3656 & 12.6 & 4137 & 14.2 & 4869 & 16.8 & 3284 & 11.3 & 16.9 \\
\hline $2081-2100$ & $\begin{array}{c}\text { Summer- } \\
\text { autumn }\end{array}$ & 9392 & 32.3 & 4326 & 14.9 & 3771 & 13.0 & 4133 & 14.2 & 4646 & 16.0 & 2780 & 9.6 & 15.0 \\
\hline
\end{tabular}

\section{Discussion.}

Based on the permissible erosion standards recommended by the National Standard of Ukraine (DSTU..., 2010), the arable land of the district with erosion losses of soil not exceeding $2 \mathrm{t} / \mathrm{ha} /$ year can be considered as erosion-safe. The estimated area of such lands in the district in 1961-1990 was about 8550 ha or $29.4 \%$ of the arable land area. Another 5510 ha or $19.0 \%$ of arable land with erosion losses of soil from 2 to $5 \mathrm{t} / \mathrm{ha}$ /year were characterized by low erosion risk. In total, these two categories of land occupied about $48 \%$ of the arable land. They either do not require special anti-erosion measures, or allow to be limited by the simple soil-protective techniques, such as plowing transversely the slope, periodic deep plowing or plowing with soil deepening, as well as phyto-reclamation techniques (Svetlichnyi et al., 2004; Naukovi ..., 2010; Zonalni..., 2010). However, almost $52 \%$ of arable land is characterized by significant erosion risk. Within 8153 ha $(28.1 \%)$, the estimated soil loss exceeds $20 \mathrm{t} / \mathrm{ha} /$ year, and therefore the erosion hazard of these lands is characterized as very high or catastrophic (with soil losses of more than $50 \mathrm{t} /$ ha/year) (Svitlychnyin and Chornyy, 2007; Tarariko et al., 2017, etc.). These lands require a set of special anti-erosion measures. Moreover, given the projected further increase in the erosion risk of arable land in the district, this requirement becomes even more urgent.

The calculations show that arable lands, on which the average annual soil loss exceeds $20 \mathrm{t} / \mathrm{ha} /$ year, cannot be protected from the progressive erosion degradation with their continued intensive use. They should be removed from the composition of the arable land. On lands with an average annual soil loss of 5-20 t/ha and moderate or high erosion hazard, it is necessary to implement the system of soil protection measures, the intensity of which is proportional to the degree of soil erosion hazard. Landscape-adaptive soil-protective farming system is by far the best option of such system. At the same time, it is necessary to emphasize the need to change the structure of sown areas here with a decrease of the share of row crops and an increase of the share of grasses, especially perennial ones. In accordance with the recommendations of agrarian science for the Western Forest-Steppe of Ukraine, even for the first (least erosion-hazardous) ecologicaltechnological group of lands, the optimal permissible limits for saturation of crop rotation with perennial grasses are 10-30\% (Tarariko, 1990). Currently, perennial grasses occupy only $3.5 \%$ of the sown area of the district (Table 2). 
Provided that 8150 hectares of the most erosionhazardous lands will be removed from the arable land and the share of perennial grasses in the crop rotation will be increased to $15 \%$ due to a corresponding decrease in the share of row crops, it is predicted that for 2031-2050 the average soil losses on arable land of the district will decrease to $3.4 \mathrm{t} / \mathrm{ha} /$ year. At the same time, lands with no or weak erosion hazard, that is, with soil losses not exceeding $5 \mathrm{t} / \mathrm{ha}$ per a year, will occupy about $65 \%$ of the arable land.

When 8150 ha will be removed from the arable land, the share of arable land in the composition of agricultural land of the district will decrease from $81.8 \%$ to $58.8 \%$. Based on a generalization of the results of studies conducted in Ukraine, Makhortov (1999) recommends the optimal share of arable land in the composition of agricultural land from the range of $45-55 \%$ for the Forest-Steppe zone. According to the research of Carik (2010) in an optimal model of the land use structure as a whole for Podillja, arable land as part of agricultural land should occupy $60 \%$ of their area, and directly for Pidhayetskyi district $-58.7 \%$. Thus, withdrawal from intensive agricultural use of lands for which the erosion losses of soil projected for 2031-2050 exceed $20 \mathrm{t} / \mathrm{ha} /$ year (Table 4), will make it possible to bring the structure of arable land to the optimum.

The erosion-hazardous lands removed from the arable land are recommended for use under hayfields, pastures or permanent afforestation with the mandatory implementation of a range of anti-erosion measures, including, if necessary, hydro reclamation measures.

\section{References}

Bulygin, S. Yu., Naring, M. A., 1999. Formirovanie jekologicheski sbalansirovanyh agrolandshaftov: problema jerozii [Formation of ecologically balanced agrolandscapes: the problem of erosion]. Eney Ltd, Kharkiv (in Russian).

Carik, L. P., 2010. Do problem optymizacii' zemle- ta pryrodokorystuvannja regionu [To the Problem of Optimization of Land and Natural Use of a Region]. Nature of Western Polesie and surrounding territories: Coll. Sc. Papers. Volyn. Lesya Ukrainka Nat. University, resp. ed. F. V. Zuzuk and others. Lutsk, № 7, 35-46 (in Ukrainian).

DSTU 7081:2009. Erozija g'runtu. Dopustymi normy, 2010 [DSTU 7081: 2009. Soil erosion. Admissible standards]. State standard of Ukraine, Kyiv (in Ukrainian).

Foster, G. R., Wishmeier, W. H., 1974. Evaluating irregular slopes for soil loss prediction. Trans. Am. Soc. Agric. Engrs., 17(2), 305-309. doi: 10.13031/2013.36846.

Geografija Ternopil's'koi' oblasti. T. 1. Pryrodni umovy ta resursy, 2017 [Geography of Ternopil region. Vol.1. Natural Conditions and Resources] / Scientific editor M. Ya. Sivyi. Vector, Ternopil (in Ukrainian).

\section{Conclusions.}

1. Most of the arable land of the Pidhayetskyi district of the Ternopil region is erosion hazardous. Under the existing structure of crop area, the estimated average annual soil losses for hydrometeorological conditions of 1961-1990 is 16.0 t/ha per a year, and land with a very high erosion hazard with annual soil losses exceeding $20 \mathrm{t} /$ ha per a year occupy $23 \%$ of the arable land.

2. Due to the projected increase in precipitation during the warm season in the middle and the end of the current century, further intensification of soil erosion is expected, especially expressed in 2031-2050, when the average annual soil losses within arable land in the district will increase to $16.9 \mathrm{t} / \mathrm{ha} /$ year, and the area of land with a very high erosion hazard will increased up to $28 \%$.

3. Ensuring the protection of arable land of the district from erosion destruction is impossible without withdraw from the arable land about 8.15 thousand hectares of the most erosion-hazardous land. This will reduce the share of arable land to $58.8 \%$ of the agricultural land, which will bring it as close as possible to the optimum and will allow to reduce soil losses due to erosion to permissible values using soil-protective landscape-adaptive farming systems.

4. In solving the problem of protecting the arable lands of the district from erosion degradation, the increase in the area of perennial grasses from $3.5 \%$ to $15 \%$ plays an important role.

Gopchenko, Ye. D., Ovcharuk, V. A., Semenova, I. G., 2012. Naukovo-metodychni pidhody do vrahuvannja global'nyh zmin klimatu pry rozrahunkah maksymal'nogo stoku richok [Scientific and methodical approaches to taking into account global climate changes in calculations of maximum runoff of rivers]. Bulletin of Odesa State Ecological University 14, 141-150 (in Ukrainian).

Hobbs, P. R.,' Sayre, K., Gupta, R., 2008. The role of conservation agriculture in sustainable agriculture. Philos. Trans. R. Soc. Lond. B. Biol. Sci.; 363(1491): 543-555. Published online 2007 Jul 24. doi: 10.1098/ rstb.2007.2169

Karta gruntiv Ukrai'ns'koi' RSR, masshtab: 1:200000, 1967 [Map of soils of the Ukrainian SSR, scale: 1: 200000] ed. Krupsky M. K. Ukrzemproject, Kyiv (in Ukrainian).

Kashtanov, A. N, Lisetskiy, F. N, Schwebs, G. I, 1994. Osnovy landshaftnogo zemledelija [Fundamentals of landscape agriculture]. Kolos, Moscow (in Russian).

Klimatychnyj kadastr Ukrai'ny: standartni klimatychni normy za period 1961-1990 pp. 2006 [Climatic Cadastre of Ukraine: standard climate norms for the period 1961- 
1990]. Electronic resource. Central Geophysical Laboratory, Kyiv (in Ukrainian).

Krakowska, S, V., Gnatyuk, N. V., Shpital, T. M., Palamarchuk, L. V., 2016. Proekcii' zmin temperatury povitrja za danymy ansamblju regional'nyh klimatychnyh modelej v regionah Ukrai'ny v XXI stolitti [Projections of changes in air temperature according to the ensemble of regional climate models in the regions of Ukraine in the 21 st century]. UkrNDGMI Scientific Papers, Issue. 268. 33-44 (in Ukrainian)..

Krakowska, S. V., Palamarchuk, L. V., Hnatyuk, N. V., Shpital, T. M., Shedenko, I. P., 2017. Zminy polja opadiv v Ukrai'ni u HHI st. za danymy ansamblju regional'nyh klimatychnyh modelej [Changes in the rainfall field in Ukraine in the 21 st century. according to the ensemble of regional climate models]. GEOINFORMATIKA. № 4(64), 62-74 (in Ukrainian).

Lavrovsky, A. B., Igumentsev, A. F., Anisimov, S. V., Schegoleva, L. G., 1987. K voprosu postroenija modeli stoka i smyva pochvy pri livnevoj jerozii [On the issue of constructing a model of runoff and soil erosion during storm erosion]. Patterns of erosion and channel processes in various environmental conditions. Moscow, 89-90 (in Russian).

Lisetskiy, F. N., Svetlitchnyi, A. A., Chornyy, S. G., 2012. Sovremennye problemy jeroziovedenija [Modern problems of erosion science]. Sc. ed. A. A. Svetlitchnyi. Constanta, Belgorod (in Russian).

Magleby, R., Sandretto, C., Crosswhite, W., Osborn, C. T., 1995. Soil Erosion and Conservation in tlie United States: An Overview. Natural Resources and Environment Division, Economic Research Service, U. S. Department of Agriculture. Agriculture Information Bulletin No. 718.

Makhortov, Yu. A., 1999. Jekologo-jekonomicheskie problemy ispol'zovanija zemel'nyh ugodij [Ecological and economic problems of land use]. Lugansk (in Russian).

Montgomery, D. R., 2007. Soil erosion and agricultural sustainability. Proc. Natl. Acad. Sci. U SA; 104(33): 13268-13272. Published online 2007 Aug 8. doi: 10.1073/pnas.0611508104.

Natsionalna dopovid pro stan rodiuchosti gruntiv Ukrainy [National report on soil fertility in Ukraine], 2010. Baliuk, S. A., Medvedev, V. V., Tarariko, O. G., Grekov O. V., Balaev, A. D. (eds). VIK PRINT, Kyiv (in Ukrainian).

Naukovi ta prykladni osnovy zahystu gruntiv vid erozii' v Ukrai'ni, 2010 [Scientific and applied bases of soil protection against erosion in Ukraine]. Bolyuk, S.A. and Tovazhnyansky, L.L. (eds). NTU "KPI", Kharkiv (in Ukrainian).

Ovcharuk, V. A., 2018. Maksymal'nyj stik vesnjanogo vodopillja richok Ukrai'ny: rozrahunkovi modeli ta i'h realizacija [Maximum runoff of spring flood waters of Ukraine: estimated models and their implementation]. Dr. (Geogr.) Sc. Theses, Odesa, Odesa State Environmental University. Retrieved from http://eprints. library.odeku.edu.ua/1015/7/Ovcharuk_Maksimalnii\%20 stik_DIS_D_2018.pdf (in Ukrainian).
PCRaster: Software for Environmental Modeling, 2018. Retrieved from http://pcraster.geo.uu.nl/.

Pidgajec'ka rajonna derzhavna administracija. Oficijnyj vebsajt, 2018. [Pidhayetska District State Administration. The official website]. Retrieved from http://www.oda. te.gov.ua/pidhaetska/ua.4873.htm (in Ukrainian).

Piatkova, A. V., 2011. Prostorove modeljuvannja vodnoi' erozii' g'runtu jak osnova naukovogo obgruntuvannja racional'nogo vykorystannja erozijno-nebezpechnyh zemel' [Spatial modeling of water soil erosion as a basis for scientific substantiation of rational use of erosionhazardous lands]. Abstract. diss. cand. geogr. Sciences, 11.00.11. Odesa St. Ecol. Univ., Odesa (in Ukrainian).

Piatkova, A. V., 2013. Urahuvannja struktury shylovogo stikannja pry prostorovomu modeljuvanni zlyvovogo zmyvu g'runtu [Consideration of slope runoff structure in spatial modeling of storm drainage]. Odesa National University Herald, Series of Geogr. and Geol. Sc., 18, 2(18), 82-87 (in Ukrainian).

Renard, K. G., Foster, G. R., Weesies, G. A., McCool, D. K., Yoder, D. C., 1997. Predicting Soil Erosion By Water: A Guide to Conservation Planning with the Revised Universal Soil Loss Equation (RUSLE)USDA Agricultural Handbook 703. U. S. Department of Agriculture, Washington DC. Retrieved from https://www.ars.usda.gov/ARSUserFiles/64080530/ RUSLE/AH_703.pdf

Rykhlivskyi, I. P, Laser, P. N, Chapai V.A., 2014. Adaptyvnolandshaftne zemlerobstvo: navchal'nyj posibnyk [Adaptive-landscape agriculture: a tutorial]. PP Zvoleyko D.G, Kamianets-Podilskyi (in Ukrainian).

Shelyakin, N. M., Belolipsky, V. A., Golovchenko, I. N., 1990. Konturno-meliorativnoe zemledelie na sklonah [Contour-reclamation agriculture on the slopes]. Urozhay, Kiev (in Russian).

Shvebs, H. I., 1974. Formirovanie vodnoj jerozii, stoka nanosov i ih ocenka [Formation water erosion, sediment runoff and evaluation]. Hydrometeoizdat, Leningrad (in Russian).

Shvebs, H. I., 1981. Teoreticheskie osnovy jeroziovedenija [Theoretical basis of soil erosion science]. Publishing House "Vishcha Schkola", Kiev-Odesa (in Russian).

Spravochnik po pochvozashhitnomu zemledeliju, 1990. [Handbook of Conservation Agriculture] / I. N. Bezruchko, L. Ya. Milchevsky eds. Urozay, Kiev (in Russian).

Sribnyi, I. K., 1977. Srednegodovoj stok vody i smyv pochvy so sklonov [The average annual runoff and flushing of soil from the slopes]. Water management on small rivers: collection. Budivelnik, Kiev, 145-147 (in Russian).

Sribnyi, I. K., Vergunov, B. A., 1993. Vyznachennja zmyvu gruntu zi shyliv [Determination of soil flushing from slopes]. Bulletin of Agrarian Science, № 7, 42-46 (in Ukrainian).

Svetlitchnyi, AA., 1995. Prostranstvenno-vremennaja ocenka livnevoj jerozii pochv [Spatio-temporal assessment of storm erosion of soils]. Deposited in the State Scientific Technical Library of Ukraine, № 1911-Uk95 (in Russian). 
Svetlitchnyi, A. A., 1999. The principals of improving empirical models of soil erosion. Euras. Soil Sci., 32(8), 917-923.

Svetlitchnyi, A. A., Chornyy, S. G., Shvebs, H. I., 2004 Jeroziovedenie: teoreticheskie i prikladne aspekty [Soil erosion science: theoretical and applied aspects]. VTD «University Book, Sumy (in Russian).

Svitlychnyi, O. O., Chornyy, S. G., 2007. Osnovy erozijeznavstva [Basics of erosion science: a textbook]. VTD «University Book», Sumy (in Ukrainian).

Svetlitchnyi, A. A., Piatkova, A. V., 2017. Ocenka adekvatnosti prostranstvennogo modelirovanija intensivnosti smyva -akkumuljacii pochvy na osnove fiziko-statisticheskoj modeli [The assessment of the adequacy of spatial modeling of the intensity of erosionaccumulation of the soil based on the physico-statistical model]. Odesa National University Herald, Series of Geogr. and Geol. Sc., 22, 2(31), 48-60 (in Russian).

Svetlitchnyi, A. A., 2018. Ocenka izmenenij gidrometeorologicheskih uslovij livnevoj jerozii pochvy v Stepi i Lesostepi Ukrainy v svjazi s izmenenijami klimata [Assessment of changes in hydrometeorological conditions of storm soil erosion in the Steppe and ForestSteppe of Ukraine in connection with climate change]. Odesa National University Herald, Series of Geogr. and Geol. Sc., 23, 1(32), 53-71 (in Russian).

Svitlychnyi, O. O., 2018. Zminy intensyvnosti vodnoi' erozii' g'runtiv u zv'jazku zi zminamy klimatu [Changes in the intensity of soil erosion due to climate change]. Agrochemistry and Soil Science. Interagency thematic scientific collection. Special issue. Book 2. Reclamation, recultivation, soil protection, agrochemistry, humus condition, soil biology, organic farming. PE «StyleIssue», Kharkiv, 125-126 (in Ukrainian).

Svetlitchnyi, A. A., Piatkova, A. V., 2019. Spatially distributed GIS-realized mathematical model of rainstorm erosion losses of soil. Journal of Geology, Geography and Geoecology, 28(3), 262-271.
Tarariko, A. G., 1990. Agrojekologicheskie osnovy pochvozashhitnogo zemledelija [Agroecological fundamentals of soil conservation agriculture]. Urozhay, Kiev (in Russian).

Tarariko, O. G., Kuchma, T. L., Ilyenko, T. V., Demianyuk, O. S., 2017. Erozijna degradacija g'runtiv ukrai'ny za vplyvu zmin klimatu [Erosion degradation of soils of Ukraine due to climate change]. Agro-ecological journal, № 1, 7-15 (in Ukrainian).

Tarariko, Yu. O., 2005. Formuvannja stalyh agroekosystem: teorija i praktyka [Formation of sustainable agroecosystems: theory and practice]. Agricultural Science, Kyiv (in Ukrainian).

Vergunov, V. A, 2006. Pryrodoohoronne adaptyvnolandshaftne melioratyvne zemlerobstvo $\mathrm{v}$ basejnah malyh richok Lisostepu Ukrai'ny [Environmental adaptive-landscape reclamation agriculture in the basins of small rivers of the Forest-Steppe of Ukraine]. Agrarian Science, Kiev (in Ukraine).

Wischmeier, W. H., Smith, D. D., 1978. Predicting rainfall erosion losses. Agric. Handbook № 537, United States Department of Agriculture, Washington, D. C. Retrieved from https://naldc.nal.usda.gov/ download/CAT79706928/PDF.

Zhidkin, A. P., Golosov, V. N., Svetlitchnyi, A. A., Pyatkova, A. V., 2015. Kolichestvennaja ocenka pereraspredelenija nanosov na pahotnyh sklonah na osnove ispol'zovanija polevyh metodov i matematicheskih modelej [Quantitative evaluation redistribution of sediment on arable slopes through the use of field methods and mathematical models]. Geomorphology, 2, 41-53 (in Russian)..

Zonal'ni metodychni rekomendacii' iz zahystu gruntiv vid erozii', 2010. [Zonal methodological guidelines for soil protection against erosion]. National Scientific Center "O. N. Sokolovsky Institute of Soil Science and Agrochemistry", Kharkiv (in Ukrainian). 